\title{
Etlik Piliç Karma Yemlerinde Farklı Yağ Kaynağı Kullanımının Büyüme Performansı ve Serum Lipit Kon- santrasyonuna Etkisi*
}

\section{Influence of Different Sources of Oil on Growth Performance and Serum Lipid Profile in Broilers}

\section{Ahmet Engin TÜZÜN*}

Aydın Adnan Menderes Üniversitesi, Koçarlı Meslek Yüksekokulu, Bitkisel ve Hayvansal Üretim Bölümü, Aydın atuzun@adu.edu.tr

(iD) 0000-0003-3493-1623

\section{Alp Önder YILDIZ}

Selçuk Üniversitesi Ziraat Fakültesi, Zootekni Bölümü, Selçuklu, Konya

aoyildiz@selcuk.edu.tr

(iD) 0000-0002-3274-7710

*Sorumlu yazar

Gönderilme Tarihi : 2 Mayıs 2020

Kabul Tarihi : 24 Mayıs 2020

${ }^{*} \mathrm{Bu}$ makale doktora tezinden üretilmiştir.

\section{Özet}

Bu çalışma, karma yemlere farklı yağ kaynağı kullanımının etlik piliçlerin büyüme performansı parametreleri ile serum trigliserit, total kolesterol, yüksek yoğunluklu lipoprotein (HDL) ve düşük yoğunluklu lipoprotein (LDL) konsantrasyonları etkilerini belirlemek amacı ile yapılmışıtır. Denemede toplam 640 adet günlük yaşta ve karışık cinsiyette etlik civciv (Ross 308) kullanılmıştır. Denemede; ayçiçek yağı, kanola yağı, sığır iç yağı (\%50 don yağ + \%50 çöz yağ) ve bu yağların eşit oranlarda karıştırılmasından (\%25 ayçiçek yağ $1+\% 25$ kanola yağ $1+\% 25$ don yağ $+\% 25$ çöz yağ) oluşan mix yağ olarak adlandırılan 4 farklı muamele grubu oluşturulmuştur. Muameleler sekiz tekerrürlü ve her tekerrürde 20 civciv olacak şekilde rastgele dağıtılmıştır. Mısır-soya esaslı başlangıç (1-21.gün; \% 23 HP, 3000 kcal/ kg ME) ve bitiş (22-42.gün; \% $20 \mathrm{HP}, 3200 \mathrm{kcal} / \mathrm{kg} \mathrm{ME)}$ yem karmalarına sırasıyla $\% 5$ ve $\% 7.5$ oranında ilgili yă kaynakları ilave edilmiștir. Deneme boyunca yem ve su $a d$ libitum olarak verilmiştir. Deneme sonuçlarına göre etlik piliç karma yemlerine farklı yağ kaynakları kullanımının canlı ağırlık artışı üzerine etkisi önemli bulunmamıştır $(\mathrm{P}>0.05)$. Ayçiçek yağ 1 ilaveli yem ile beslenen piliçlerin yem tüketimi ve yemden yararlanma oranı kanola yağı ilaveli 
yem ile beslenen piliçlerle benzer, iç ve mix yağ ilaveli yem ile beslenen piliçlerden önemli seviyede düşük olmuştur $(\mathrm{P}<0.05)$. Etlik piliç karma yemlerine farklı yağ kaynakları ilavesinin serum trigliserit, total kolesterol, HDL ve LDL konsantrasyonu üzerine etkisi önemli olmamıştır ( $\mathrm{P}>0.05)$. Ancak erkek piliçlerin serum total kolesterol, HDL ve LDL konsantrasyonları dişi piliçlerden daha yüksek olmuştur $(\mathrm{P}<0.05)$. Etlik piliç rasyonlarında ayçiçeği yağı kullanımının performansı diğer yağ kaynaklarına göre iyileştirdiği ve hayvansal yağların bitkisel yağlar ile karışım olarak kullanılmasının daha iyi olduğu ve yağ kaynaklarının serum lipitlerini etkilemediği görülmüştür.

Anahtar kelimeler: Etlik piliç, performans, yağ kaynağ1, HDL, LDL

\section{Abstract}

This study examined the effect of different oil sources use on the growth performance blood serum lipid profile of broilers. In the experiment, a total of 640 1-day-old unsexed broiler chicks were used. The dietary treatments were sunflower oil (SO), canola oil (CO), tallow (T) and the mixture of these oils in equal proportions. Thus, chicks were randomly distributed four dietary treatments with eight replications each has 20 chicks. The oil sources were supplemented to corn-soybean meal based starter ( 1 to $21 \mathrm{~d}$; \% 23 $\mathrm{CP}, 3000 \mathrm{kcal} \mathrm{ME} / \mathrm{kg}$ ) and finishing feeds (22 to $42 \mathrm{~d} ; \% 20 \mathrm{CP}, 3200 \mathrm{ckal} \mathrm{ME} / \mathrm{kg}$ ) at inclusions levels of $5 \%$ and $7.5 \%$, respectively. During the six-week trial, feed and water were given as $\mathrm{ad}$ libitum. As a result of the experiment, the use of different fat sources in broiler feed has no significant effect on body weight gain $(\mathrm{P}>0.05)$.
The feed intake and feed conversion ratio of the chickens fed with sunflower oil supplement was similar to the chickens fed with canola oil supplemented feed, and significantly lower than the chickens fed with feedstuff and mixed oil supplement $(\mathrm{P}<0.05)$. The addition of different fat sources to broiler feeds had no significant effect on serum triglyceride, total cholesterol, HDL and LDL concentrations $(\mathrm{P}>0.05)$. However, the total cholesterol, HDL and LDL concentrations of male broilers were higher than the female broilers $(\mathrm{P}<0.05)$. It is concluded that the use of sunflower oil in broiler diets improves performance over other fat sources without no significant effect on serum lipid profile. It is data from the present experiment also suggest to use animal fats in mixtures with oils to increase their metabolizibility rather than theirs single use in the fed.

Keywords: Broiler, performance, oil source, HDL, LDL

\section{GIRIŞ}

Hızlı büyüme ve yüksek et verimi için geliştirilen modern etlik piliç hibritlerinin enerji ihtiyacını karşılamak amacı ile yağlar karma yemlerde enerji kaynağı olarak kullanılırlar. Çünkü yağların enerji değeri karbonhidrat ve proteinlerden en az iki kat daha yüksektir (NRC, 1994). Ancak yağların enerjisinden yararlanma etkinliği üzerine birçok faktör etki etmektedir. Bunlar serbest yağ asitleri içeriği, yapısında bulunan yağ asitlerinin zincir uzunlukları ve çift bağ sayıları, yağın ilave edildiği karma yemin yapısı ve yağın katılma düzeyi, hayvanın yaşı, yağların ekstra dinamik ve metabolik etkileridir (Kırkpınar vd., 1999).Yağlar karma yemlerde 
enerji ihtiyacını karşılamanın yanı sıra lezzetlilik, tozumayı önleme, kullanılan ekipmanların aşınmasını önleme ve yağda çözünen vitaminlerin daha iyi emilimini sağlamak gibi faydalar da sağlar (Firman vd., 2008). Ayrıca, yağlar besinlerin sindirim sisteminden geçiş hızını yavaşlatarak besin maddelerinin emilimi artırır (NRC, 1994). Bu amaçla, etlik piliç karma yemlerine bitkisel ve hayvansal yağlar ile yağ sanayi yan ürünleri ve geri kazanılmış kızartma yağları kullanılabilmektedir (Ravindran vd., 2016). Yağların ana bileşeni yağ asitleridir. Bitkisel ve hayvansal yağların yağ asidi bileşimi farklılık gösterir. Doymamış yă̆ asitleri bakımından zengin bitkisel sıvı yağların doymuş yağ asitleri bakımından zengin hayvansal don yağlara kıyasla sindirim ve absorbsiyonu daha yüksektir (Scaife vd., 1994; Crespo ve EstevaGarcia 2002). Bitkisel ve hayvansal yağlar karma yemlerde karışım halinde kullanıldı ̆̆ında ise sinerjik etki oluşturarak sindirim ve absorbsiyonu artırmaktadır (Baião ve Lara, 2005). Etlik piliçlerde karma yemde kullanılan yağ kaynağı serum lipit konsantrasyonunu etkilemektedir (Donaldson, 1979; Tepperman, 1981). Etlik piliç karma yemlerinde kullanılan doymamış yağlar doymuş yağlara göre serum LDL konsantrasyonunu azaltip serum HDL konsantrasyonunu arttırmaktadır (Kinsella vd., 1990; Duraisamy vd., 2013). Yüksek serum LDL konsantrasyonu ise adipoz dokularda yağ depolanmasını arttırmaktadır (Zammit vd., 2001). Ayrica karma yemlerde kullanılan yağ kaynağ1 serum lipit konsantrasyonunu etkileyerek piliç etinin organoleptik özellikleri ve kalitesi üzerinde etkili olmaktadır (Zollitsch vd., 1997).
$\mathrm{Bu}$ çalışma etlik piliç karma yemlerinde kullanılan ayçiçek yağı, kanola yağı, sığır iç yağı ve bu yağların karışımından oluşan yağ kaynaklarının etlik piliçlerin büyüme performans1 ve serum lipit konsantrasyonuna etkisini belirlemek amacı ile yapılmıştır.

\section{MATERYAL VE YÖNTEM}

Araştırmada hayvan materyali olarak 640 adet günlük yaşta ve karışık cinsiyette etlik civciv (Ross 308) kullanılmıştır. Denemede; ayçiçek yağı, kanola yağı, sığır iç yağı [(\%50 don yağ (işkembe etrafındaki yağ) + \%50 çöz yă̆ (bağırsak etrafındaki yağ)] ve bu yağların eşit oranlarda karıştırılmasından (\%25 ayçiçek yağı $+\% 25$ kanola yağ $1+\% 25$ don yağ $+\% 25$ çöz yağ) oluşan mix yağ olarak adlandırılan 4 farklı yağ kaynağ 1 kullanılmıştır. Hayvanlar 4 farklı karma yemle yemlenecek şekilde her biri sekiz tekerrürlü 4 gruba ayrılarak her alt grupta 20 hayvan olmak üzere 32 alt gruba ayrılmıştır. Başlatma yemi (0-21.gün; \% 23 HP, 3000 kkal $\mathrm{ME} / \mathrm{kg}$ ) \%5 ve bitirme yemi (22-42.gün; (\% 20 HP, $3200 \mathrm{kkal} \mathrm{ME} / \mathrm{kg}$ ) \%7.5 seviyesinde dört farklı yağ kaynağından ilave edilerek misırsoya küspesi ağırlıklı, denemede kullanılan hibridin besin madde ihtiyaçlarını içeren katalog değerleri dikkate alınarak izokalorik ve izonitrojenik olarak hazırlanmıştır (Çizelge 1). Denemede, "23 saat ışık - 1 saat karanlık" aydınlatma programı uygulanmış, yem ve su ad-libitum verilmiştir. Denemede hayvanlar 21. ve 42. günlerde grup tartımı yapılarak canlı ağırlıklar tespit edilmiş ve bu rakamlardan canlı ağırlık artışları (CAA) hesaplanmıştır. Gruplara yemler tartılarak verilmiş ve yemlikte kalan ve dökülen yemler toplam yemden çıkarılarak 21. ve 42. günlük yem tüketimi (YT) tespit 
Çizelge 1. Deneme karma yemlerinin hammadde ve hesaplanmış besin maddesi kompozisyonu

Başlatma Bitirme

\begin{tabular}{|c|c|c|c|c|c|c|c|c|}
\hline \multirow[b]{2}{*}{ Hammaddeler } & & & & & \\
\hline & 1 & 2 & 3 & 4 & 1 & 2 & 3 & 4 \\
\hline Misir & 48.90 & 48.90 & 51.25 & 51.25 & 51.50 & 51.50 & 53.70 & 52.70 \\
\hline SFK (\%47.6) & 39.00 & 39.00 & 37.00 & 37.00 & 32.80 & 32.80 & 33.20 & 33.00 \\
\hline Misir gluteni & 1.50 & 1.50 & 3.00 & 3.00 & - & - & - & - \\
\hline Buğday kepeği & 1.85 & 1.85 & - & - & 5.00 & 5.00 & 2.36 & 3.60 \\
\hline Ayçiçek yağ1 & 5.00 & - & - & - & 7.50 & - & - & - \\
\hline Kanola yağ1 & - & 5.00 & - & - & - & 7.50 & - & - \\
\hline S1ğır iç yağ1 & - & - & 5.00 & - & - & - & 7.50 & - \\
\hline Mix yağ & & & & 5.00 & & & & 7.50 \\
\hline Mermer tozu & 1.31 & 1.31 & 1.31 & 1.31 & 1.40 & 1.40 & 1.39 & 1.37 \\
\hline DCP & 1.62 & 1.62 & 1.64 & 1.64 & 1.07 & 1.07 & 1.12 & 1.10 \\
\hline Tuz & 0.35 & 0.35 & 0.35 & 0.35 & 0.35 & 0.35 & 0.35 & 0.35 \\
\hline $\begin{array}{l}\text { Vit. ve Min. } \\
\text { Premiksi* }\end{array}$ & 0.25 & 0.25 & 0.25 & 0.25 & 0.25 & 0.25 & 0.25 & 0.25 \\
\hline Metiyonin & 0.22 & 0.22 & 0.20 & 0.20 & 0.13 & 0.13 & 0.13 & 0.13 \\
\hline \multirow[t]{2}{*}{ Toplam } & 100.00 & 100.00 & 100.00 & 100.00 & 100.00 & 100.00 & 100.00 & 100.00 \\
\hline & \multicolumn{8}{|c|}{ Hesaplanmış Besin Madde Kompozisyonu } \\
\hline $\mathrm{ME}, \mathrm{kcal} / \mathrm{kg}$ & 3016 & 3016 & 2997 & 3012 & 3201 & 3201 & 3199 & 3202 \\
\hline Ham protein, $\%$ & 23.05 & 23.05 & 22.99 & 22.99 & 20.00 & 20.00 & 20.00 & 20.00 \\
\hline Ham yağ, \% & 7.48 & 7.48 & 7.54 & 7.54 & 10.09 & 10.09 & 10.07 & 10.08 \\
\hline Kalsiyum, \% & 1.00 & 1.00 & 1.00 & 1.00 & 0.89 & 0.89 & 0.90 & 0.89 \\
\hline Kull.fosfor, \% & 0.45 & 0.45 & 0.45 & 0.45 & 0.35 & 0.35 & 0.35 & 0.35 \\
\hline Lisin, $\%$ & 1.23 & 1.23 & 1.18 & 1.18 & 1.06 & 1.06 & 1.06 & 1.06 \\
\hline Metiyonin, \% & 0.51 & 0.51 & 0.51 & 0.51 & 0.38 & 0.38 & 0.38 & 0.38 \\
\hline Met.+ Sis., \% & 0.97 & 0.97 & 0.94 & 0.94 & 0.78 & 0.78 & 0.78 & 0.78 \\
\hline
\end{tabular}

${ }^{\bar{*}}$ Vitamin ve Mineral Premiksi $1 \mathrm{~kg}$ yem karmasına; 12000IU Vit A, 1500IU Vit D3, 30mg Vit E, 5mgVit K, 3mg Vit B1, $6 \mathrm{mg}$ Vit B2, 5mg Vit B6, 0.03mg Vit B12, 40mg Nikotin amid, 10mg Kalsiyum DPantotenat,0.75mg Folik asit, $375 \mathrm{mg}$ Kolin Klorid Vitaminleri, 10mg Antioksidant, 100mg Manganez,60 mg Demir, $10 \mathrm{mg}$ Bakır, $0.20 \mathrm{mg}$ Kobalt, $1 \mathrm{mg}$ İyot ve $0.15 \mathrm{mg}$ Selenyum sağlamaktadır.

edilmiştir. Yemden yararlanma oranı (YYO) ise YT/CAA formülüyle hesaplanmıştır. Kan değerleri ile ilgili verileri ise deneme sonunda; her bir alt gruptan ortalama canlı ağırlığa en yakın rastgele seçilen 2 erkek ve 2 dişi piliçten kanat damarından tüplere 10 cc kan örnekleri alınmıştır. Kan örnekleri 3000 devir/dakika'da 10 dakika santrifüj edilerek serumları çıkarılmıştır. Serum biyokimyasal analizleri (Trigliserit, Total kolesterol, HDL ve LDL) I-LAB 300 marka biyokimya otoanalizöründe aynı firmanın kitleri kullanılarak yapılmıştır.

\section{İstatistik analiz}

Muamelelerin incelenen parametrelere etkilerinin önemli olup olmadığını tespit etmek için toplanan performans ve serum parametreleri istatistik paket programı (SAS, 2002) kullanılarak varyans analizi uygulanmıştır. Grup ortalaması arasındaki farklılıklar LSD testi (The 
Çizelge 2. Karma yemlerinde kullanılan farklı yağ kaynaklarının etlik piliçlerin büyüme performansına etkisi

\begin{tabular}{|c|c|c|c|c|c|c|}
\hline Dönemler & $\begin{array}{c}\text { Ayçiçek } \\
\text { yağı }\end{array}$ & $\begin{array}{c}\text { Kanola } \\
\text { yağı }\end{array}$ & $\begin{array}{c}\text { İç } \\
\text { yağ }\end{array}$ & Mix yağ & $\mathrm{SHO}^{1}$ & $\begin{array}{c}P \\
\text { değeri }\end{array}$ \\
\hline \multicolumn{7}{|l|}{ 1-21.gün } \\
\hline Başlangıç canlı ağırlı̆̆ı & 38.06 & 39.58 & 39.43 & 38.08 & 0.310 & 0.873 \\
\hline $\mathrm{CAA}^{*}$ & $752^{b^{* *}}$ & $795^{\mathrm{a}}$ & $789^{\mathrm{a}}$ & $796^{\mathrm{a}}$ & 10.30 & 0.020 \\
\hline YT & $1218^{b}$ & $1289^{a}$ & $1267^{\mathrm{ab}}$ & $1268^{\mathrm{ab}}$ & 22.59 & 0.018 \\
\hline YYO & 1.63 & 1.62 & 1.61 & 1.60 & 0.034 & 0.916 \\
\hline \multicolumn{7}{|l|}{ 22-42.gün } \\
\hline CAA & $1625^{\mathrm{a}}$ & $1587^{\mathrm{ab}}$ & $1552^{\mathrm{b}}$ & $1596^{\mathrm{ab}}$ & 17.63 & 0.050 \\
\hline YT & $3072^{\mathrm{C}^{* * *}}$ & $3116^{\mathrm{BC}}$ & $3203^{\mathrm{AB}}$ & $3248^{\mathrm{A}}$ & 34.22 & 0.005 \\
\hline YYO & $1.89^{\mathrm{C}}$ & $1.96^{\mathrm{B}}$ & $2.06^{\mathrm{A}}$ & $2.04^{\mathrm{A}}$ & 0.021 & 0.001 \\
\hline \multicolumn{7}{|l|}{ 1-42.gün } \\
\hline CAA & 2377 & 2381 & 2341 & 2391 & 23.37 & 0.476 \\
\hline YT & $4290^{b}$ & $4405^{\mathrm{ab}}$ & $4470^{\mathrm{a}}$ & $4516^{\mathrm{a}}$ & 48.76 & 0.020 \\
\hline YYO & $1.81^{\mathrm{C}}$ & $1.85^{\mathrm{BC}}$ & $1.91^{\mathrm{A}}$ & $1.89^{\mathrm{AB}}$ & 0.019 & 0.006 \\
\hline
\end{tabular}

${ }_{*}^{\circ} \mathrm{CAA}$ :Canlı ağırlık artıș (g); YT:Yem tüketimi (g/piliç); YYO:Yemden yararlanma oranı (g YT/g CAA).

**a-c: Aynı satirda farkli harf tasiyan ortalamalar arasindaki farklıliklar önemlidir $(\mathrm{P}<0.05)$.

*** Aynı satırda farklı harf taşıyan ortalamalar arasındaki farklılıklar önemlidir $(\mathrm{P}<0.01)$.

${ }^{1}$ Standart hata ortalamaları.

Least Significant Difference) ile belirlenmiştir. İncelenen kan özelliklerinin hiçbiri için grup $\times$ cinsiyet interaksiyonu önemli çıkmadığından modele dahil edilmemiştir.

\section{ARAŞTIRMA SONUÇLARI ve TARTIŞMA Performans}

Muamelelerin performans parametrelerine etkisi Çizelge 2'de gösterilmiştir. Başlangıç canlı ağırlıkları bakımından gruplar arasında istatistiki farkl111k olmaması civcivlerin gruplara düzgün dağıtıldığını göstermesi bakımından önemlidir. Karma yemlerde farklı yağ kaynağı kullanımının etlik piliçlerin CAA'na denemenin birinci (1-21. günler) ve ikinci (22-42. günler) periyotlarında etkisi önemli olurken $(\mathrm{P}<0.05)$, deneme boyunca (1-42. gün) bu etki gözlenmemiştir ( $\mathrm{P}>0.05)$. Denemenin birinci döneminde ayçiçek yağı ilave edilen yemle beslenen etlik piliçlerin CAA değeri diğer muamele gruplara göre önemli derecede düşük bulunmuştur $(\mathrm{P}<0.05)$. Denemenin ikinci periyodunda ise en yüksek CAA birinci periyodun aksine ayçiçek yağı ilave edilen yemle beslenen etlik piliçlerde elde edilmiş olup, CAA bakımından ayçiçek yağı ve iç yağ grupları arasındaki farklı1ık önemli olurken diğer gruplar ile arasında farklılık olmamıştır.

Crespo ve Esteve-Garcia (2001) etlik piliç karma yemlerinde don yağı, zeytin yağı, ayçiçek yağı ve keten tohumu yağını $\% 6$ ve $\% 10$ seviyesinde kullanarak yaptıkları bir çalışmada farklı yağ kaynakları ve yağ seviyesinin CAA üzerine önemli bir etkisinin olmadığını bildirmişlerdir. Benzer şekilde De Witt vd. (2009), etlik piliç karma yemlerinde $\% 3$ ve $\% 6$ seviyesinde ayçiçek yağı, yüksek oleik asitli ayçiçek yağı, balık yağı ve don yağı ilavesinin CAA'na yağ kaynağının herhangi bir etkisinin olmadığını bildirmişlerdir. $\mathrm{Bu}$ sonuçlar ile mevcut denemeden (1-42. gün) elde edilen sonuçlar arasında bir uyum 
söz konusudur. Denemenin birinci $(\mathrm{P}<0.05)$ ve ikinci $(\mathrm{P}<0.05)$ periyotları ile deneme boyunca $(\mathrm{P}<0.05)$ muamelelerin YT'ye etkisi istatistiki olarak önemli olmuştur. Denemenin bütün periyotlarında en düşük YT ayçiçek yağı ilave edilen grupta elde edilmiş ve bu grup ile birinci periyotta kanola yağ 1 ilave edilen grup arasındaki, ikinci periyot ve tüm deneme boyunca iç yağ ve mix yağı ilave edilen gruplar arasındaki farklılıklar önemli olmuştur $(\mathrm{P}<0.05)$. Aynı zamanda ikinci periyotta kanola yağı ve mix yağ arasındaki farklılık da istatistiki olarak önemli olmuştur $(\mathrm{P}<0.05)$. Crespo ve Esteve-Garcia (2001) etlik piliçlerde farklı yağ kaynakları ile yapmış oldukları çalışma sonucunda, rasyona zeytin yağ1, ayçiçek yağ1 ve keten tohumu yağı ilave edilen grupların YT'lerinin don yağ ilave edilen gruptan önemli seviyede düşük olduğunu bildirmişlerdir. Newman vd. (2002); Crespo ve Esteve-Garcia (2002); Ferrini vd. (2008) ve Smink vd. (2010) yaptıkları çalışmalarında yağların etlik piliçler tarafindan kullanım etkinliğinin, doymuş yağ asitleri oranına bağlı olduğunu ve etlik piliçlerin enerji ihtiyaçlarını karşılamak için artan doymuşluk oranı ile birlikte yem tüketimlerinin de arttığını bildirmişlerdir. Mevcut denemede kullanılan karma yemlerin izokalorik ve izonitrojenik olarak hazırlandığı göz önünde bulundurulursa ayçiçek yağı ilave edilen grubun düşük YT'ine rağmen etlik piliçlerin enerji gereksinimlerini iç yağ ve mix yağ gruplarına göre daha iyi karşıladığı söylenebilir. Birinci periyotta YYO muamelelerden etkilemezken $(\mathrm{P}>0.05)$, ikinci periyotta ve deneme boyunca YYO muamelelerden önemli derecede etkilenmiştir $(\mathrm{P}<0.01)$. Denemenin ikinci periyodunda en iyi
YYO ayçiçek yağı ilave edilen grupta olmuş ve diğer gruplar ile arasındaki farklılıklar önemli bulunmuştur. Yine kanola yağı ile diğer gruplar arasında YYO bakımından farklılıklar önemli olurken, iç yağ ve mix yağ arasındaki YYO benzer bulunmuştur. Denemenin 1-42. günlerinde en düşük YYO ayçiçek yağ1 ilave edilen grupta elde edilmiş ve bu grup ile iç ve mix yağ ilave edilen gruplar arasındaki farklılıklar önemli olmuştur $(\mathrm{P}<0.05)$. Velasco vd. (2010) etlik piliç karma yemlerinde palmiye ve ayçiçek yağlarını \%9 seviyesinde kullanarak yaptıkları çalışmada, ayçiçeği yağı ilave edilen yemle beslenen grupların YYO bakımından palmiye yağı ilave edilen gruba göre deneme boyunca daha iyi olduğunu bildirmişlerdir. Zollitsch vd. (1997), Sanz vd. (2000), Crespo ve Esteve-Garcia (2001), Villaverde vd. (2004), De Witt vd. (2009); karma yemlerde yağ kaynağının doymamışlık derecesi arttıkça yemlerin sindirilebilirliğinin artığını ve sonuç olarak da YYO'nın iyileştiğini bildirmişlerdir. Etlik civcivler ilk hafta yetersiz safra sekresyonu ve düşük lipaz aktivitesine sahip oldukları için özellikle doymuş yağ asitlerinin sindirilebilirliği olumsuz etkilenmektedir (Mossab vd. 2000). Ancak De Witt vd. (2009) karma yemlerde yă seviyesi azaldıkça doymuş yağ içeren gruplarda YYO'nun iyileştiğini bildirmiştir. Mevcut denemenin ilk periyodunda YYO'nun gruplar arasında önemsiz olmasının muhtemel nedeni başlatma yemlerinde kullanılan yağ kaynağ seviyesi (\%5) olabilir. Ancak denemenin ikinci periyodunda karma yemlerde artan yağ seviyesi (\%7.5) ile birlikte muamele grupları arasında önemli farklılıklar oluşmuş ve bu durum deneme sonucuna da yansımıștır. Noy ve Sklan (1996) 
doymamış yağ asitlerinin etlik piliçlerde ilk hafta yetersiz olan safra sekresyonu ve lipaz aktivitesini teşvik ettiğini bildirmişlerdir. Mevcut denemede artan yağ seviyesi ile birlikte safra sekresyonunun ve lipaz aktivitesinin artmış olabileceği düşünülmektedir. Ayrıca doymamış yağların $\beta$-oksidasyon hızının doymuş yağlara kıyasla daha yüksek olduğu (Sanz vd., 2000) ve doymamış yağların endojen yağ asidi sentezini azalttığ 1 bildirilmektedir (Chen ve Chiang 2005). Bahsedilen metabolik süreçler mevcut denemede de görüldüğü gibi etlik piliçlerde doymamış yağ etkisi Çizelge 3'de verilmiştir. Karma yemlerde farklı yağ kaynağı kullanımının etlik piliçlerde serum lipit konsantrasyonuna etkisi önemsiz olmuştur $(\mathrm{P}>0.05)$. Ancak erkek piliçlerin total kolesterol, HDL ve LDL değerleri dişi piliçlerden daha yüksek olmuştur $(\mathrm{P}<0.05)$. Cinsiyetin serum trigliserit konsantrasyonuna etkisi ise önemsiz olmuştur ( $\mathrm{P}>0.05)$.

Özdoğan ve Akşit (2003), rasyon yağ asitleri bileşiminin serum total trigliserit seviyesini etkilememesine rağmen; serum kolesterol, HDL ve LDL konsantrasyonlarını önemli seviyede

Çizelge 3. Karma yemde kullanılan farklı yağ kaynaklarının etlik piliçlerin serum lipit konsantrasyonuna etkisi

\begin{tabular}{|c|c|c|c|c|}
\hline Gruplar & Trigliserit & Total Kolesterol & HDL & LDL \\
\hline Ayçiçek yağ & 54.97 & 99.53 & 76.22 & 32.41 \\
\hline Kanola yağ & 58.53 & 96.16 & 78.31 & 32.69 \\
\hline İç yağ & & 100.09 & 77.28 & 36.44 \\
\hline Mix yă̆ & $\begin{array}{l}58.44 \\
59.19\end{array}$ & 101.12 & 77.25 & 36.44 \\
\hline $\mathrm{SHO}^{1}$ & 2.61 & 3.45 & 1.82 & 1.66 \\
\hline$P$ değeri & 0.376 & 0.202 & 0.126 & 0.296 \\
\hline \multicolumn{5}{|l|}{$\underline{\text { Cinsiyet }}$} \\
\hline Erkek & 59.92 & $103.00^{\mathrm{a}}$ & $79.69^{a}$ & $36.48^{\mathrm{a}}$ \\
\hline Dişi & 55.64 & $95.45^{b}$ & $75.09^{b}$ & $32.50^{\mathrm{b}}$ \\
\hline $\mathrm{SHO}^{1}$ & 1.84 & 2.40 & 1.26 & 1.20 \\
\hline$P$ değeri & 0.105 & 0.029 & 0.011 & 0.019 \\
\hline
\end{tabular}

*a-b. Aynt satırda farkht harf taşıyan ortalamatar arasmndaki farkthtıkłar önemtidir ( $(\mathrm{P}<0.05)$.

${ }^{1}$ Standart hata ortalamalar1.

kaynaklarından (ayçiçek ve kanola yağı) elde edilen enerjinin metabolik amaçlar için kullanım etkinliğinin doymuş yağ kaynaklarından daha yüksek olmasına sebep olmuş olabilir.

\section{Serum Lipit Parametreleri}

Etlik piliç rasyonlarında farklı yağ kaynaklarının serum trigliserit, total kolesterol, HDL ve LDL değiştirdiğini; bitkisel kaynaklı tekli ve çoklu doymamış yağ asitlerince zengin rasyonların serum HDL konsantrasyonlarını artırıp LDL konsantrasyonunu azalttığını; hayvansal iç yağın ise serum HDL konsantrasyonunu azaltıp LDL konsantrasyonunu arttırdığını bildirmiştir. Burlikowska vd. (2010), etlik piliç rasyonlarına farklı yağ kaynakları (soya yağı, bitkisel karışım 
yağ ve domuz yağı) ilavesinin performans ve serum total kolesterol, trigliserit, HDL ve LDL değerlerine önemli bir etkisinin olmadığını bildirmişlerdir. Yine aynı şekilde, Monfaredi vd. (2011) düşük enerji içeren etlik piliç karma yemlerine $\% 2$ ve $\% 4$ seviyelerinde ilave edilen farklı yağ kaynaklarının (soya yağı ve sığır iç yağ1) total kolesterol, trigliserit, HDL ve LDL değerlerine herhangi bir etkisinin olmadığını ifade etmişlerdir. Mevcut denemeye ait sonuçlar ile Burlikowska vd. (2010) ve Monfaredi vd. (2011)'nın yapmış oldukları çalışmalar arasında uyum söz konusudur. $\mathrm{Bu}$ durumun karma yemde kullanılan yağ kaynağı seviyesinden kaynaklanmış olabileceği söylenebilir. Ayrıca, erkek etlik piliçlerin serum trigliserit, HDL ve LDL değerleri dişi piliçlerden önemli düzeyde yüksek olmuştur. Demir ve Öztürkcan (1991) ve Hassan vd. (2007) erkek piliçlerin serum total kolesterol ve LDL değerlerinin dişi piliçlerden daha yüksek olduğunu; Musa vd. (2006) da cinsiyetin serum trigliserit ve LDL konsantrasyonunu etkilediğini, erkek piliçlerde serum trigliserit ve LDL düzeyinin daha yüksek olduğunu bildirmişlerdir. Ayrıca Robertson ve Cumming (1985), C-peptit oranları ile serum lipoprotein konsantrasyonu arasındaki ilişkinin cinsiyete göre farklılaştığını, erkek piliçlerde C-peptit oranının daha yüksek olduğunu bunun sonucunda da erkek piliçlerin serum lipoprotein konsantrasyonlarının dişi piliçlerden daha yükssek olduğunu bildirmişlerdir. Mevcut denemeden elde edilen serum total kolesterol, HDL ve LDL sonuçlarının erkek piliçlerde anlamlı şekilde daha yüksek olmasının nedeninin C-peptit oranı olduğu söylenebilir.

\section{SONUÇ}

Etlik piliç karma yemlerinde farklı yağ kaynağ1 kullanımı canlı ağırlık artışını önemli olarak etkilememiştir. Doymamış yağ asidi içeren yăg kaynakları (ayçiçek ve kanola yağı) etlik piliç karma yemlerine ilave edildiğinde yem tüketimi azalmış yemden yararlanma oranı ise iyileşmiştir. Ayrıca doymamış yağ kaynakları (ayçiçek ve kanola yağı) ile doymuş yağ kaynağı (sığır iç yağ) karışım halinde karma yemlere ilave edildiğinde etlik piliçlerin yemden yararlanma oranı iyileşmiştir. Denemenin ilk periyodunda (1-21.gün) karma yemlerde düşük düzeyde (\%5) kullanılan iç yă̆ ilave edilen yemin etlik piliçler tarafından kullanım etkinliği diğer muamele grupları ile benzer olmuştur. Buna dayanarak doymuş yağ asidi içeren iç yağların etlik piliç karma yemlerine ilave edilme düzeyinin doymamış yağ kaynaklarından daha düşük olması gerektiği sonucu çıkarılabilir. Ayrıca, serum lipitlerine cinsiyetin etkisi farklı yă̆ kaynaklarının ve seviyelerinin kullanıldığ başka çalışmalarla araştırılmalıdır.

\section{KAYNAKLAR}

Baião NC, Lara L 2005. Oil and fat in broiler nutrition. Revista Brasil Ciên Avíc. 7, 129141.

Burlikowska K, Piotrowska A, Szymeczko R 2010. Effect of dietary fat type on performance, biochemical indices and fatty acids profile in the blood serum of broiler chickens. J. Anim. Feed Sci. 19, 440-451.

Chen HY, Chiang SH, 2005. Effect of dietary polyunsaturated/saturated fatty acid ratio on heat production and growth 
performance of chicks under different ambient temperature. Anim. Feed Sci. Technol. 120, 299-308.

Crespo N, Esteve-Garcia E 2001. Dietary fatty acid profile modifies abdominal fat deposition in broiler chickens. Poultry Sci. 80(1), 71-78.

Crespo N, Esteve-Garcia E 2002. Nutrient and fatty acid deposition in broilers fed different dietary fatty acid profiles. Poult. Sci. 81, 1533-1542.

De Witt F, Els S, Van der Merwe H, Hugo A, Fair M 2009. Effect of dietary lipid sources on production performance of broilers. S. Afr. J. Anim. Sci., 39, 45-48.

Demir E, Öztürkcan O 1991. The factors causing by fattening in broiler and their control. Broylerlerde yağlanmaya etki eden faktörler ve kontrolü. Anim. Mag. 5:39-45.

Donaldson WE 1979. Regulation fatty acid synthesis. Fed. Proc. 38, 2617-2621.

Duraisamy K, Senthilkumar M, Mani K 2013. Effect of saturated and unsaturated fat on the performance, serum and meat cholesterol level in broilers. Vet. World. 6, 159-162.

Ferrini G, Baucells MD, Esteve-Garcia E, BarroetaAC 2008. Dietary polyunsaturated fat reduces skin fat as well as abdominal fat in broiler chickens. Poult. Sci. 87, 528535.

Firman JD, Kamyab A, Leigh H 2008. Comparison of fat sources in rations of broilers from hatch to market. Int. J. Poult. Sci. 7, 1152-1155.

Hassan HM, Guo HC, Jin HC, Galal MY 2007.
Relation between abdominal fat and serum cholesterol, triglycerides, and lipoprotein concentrations in chicken breeds. Turk. J. Vet. Anim. Sci. 31(6), 375-379.

Kirkpınar F, Taluğ AM, Erkek R, Sevgican F 1999. Etlik piliç karma yemlerine ilave edilen değişik yağların performans ve yağlanma ile ilgili bazı parametreler üzerine etkileri. Turk J. Vet. Anim. Sci. 23, 523-532.

Kinsella JE, Lokesh B, Stone R 1990. Dietary n-3 polyunsaturated fatty acids and amelioration of cardiovascular disease: possible mechanisms. Am. J. Clin. Nutr. $52,1-28$.

Monfaredi A, Rezaei M, Sayyahzadeh H 2011. Effect of supplemental fat in low energy diets on some blood parameters and carcass characteristics of broiler chicks. S Afr J Anim Sci, 41(1), 24-32.

Mossab A, Hallouis JM, Lessire M 2000. Utilization of soybean oil and tallow in young turkeys compared with young chickens. Poult. Sci. 79:1326-1331.

Musa HH, Cheng JH, Wu XS, Ju HP, Mekki DM, Chen GH 2007. Analysis of LDL receptor mRNA expression, serum biochemical and abdominal fat weight in fat and lean chickens. Biol Sci. 7, 693-696.

Newman RE, Bryden WL, Fleck E, Ashes JR, Buttemer WA, Storlien LH, Downing JA 2002. Dietary n-3 and n-6 fatty acids alter avian metabolism: Metabolism and abdominal fat deposition. Br. J. Nutr. 88, 11-18.

Noy Y, Sklan D 1996. Uptake capacity in vitro for glucose and methionine and in situ for 
oleic acid in the proximal small intestine of post hatch chicks. Poult Sci. 75, 9981002.

NRC 1994. National research council nutrient requirements of poultry, 9th ed. National Academy Press, Washington, DC.155p.

Özdoğan M, Akşit M 2003. Effects of feeds containing different fats on carcass and blood parameters of broilers. J. Appl. Poulty. Res. 12, 251-256.

Ravindran V, Tancharoenrat P, Zaefarian G, Ravindran G 2016. Fats in poultry nutrition: Digestive physiology and factors influencing their utilization. Anim. Feed Sci. Technol. 213, 1-21.

Robertson FW, Cumming AM 1985. Effects of apoprotein E polymorphism on serum lipoprotein concentration. Arteriosclerosis, 5: 283-292.

Sanz M, Lopez-Bote CJ, Menoyo D, Bautista JM 2000. Abdominal fat deposition and fatty acid synthesis are lower and $\beta$-oxidation is higher in broiler chickens fed diets containing unsaturated rather than saturated fat. J Nutr. 130, 3034-3037.

SAS Institute 2002. JMP ${ }^{\circledR}$ User's Guide: Statistics Version 5.0.1.edition. SAS Institute Inc., Cary, North Caroline.

Scaife JR, Moyo J, Galbraith H, Michie W, Campbell W 1994. Effect of different dietary supplemental fats and oils on the tissue fatty acid composition and growth of female broilers. Brit. Poultry Sci. 35(1), 107-118.

Smink W, Gerrits W, Hovenier R, Geelen M, Verstegen M, Beynen A 2010. Effect of dietary fat sources on fatty acid deposition and lipid metabolism in broiler chickens. Poult. Sci. 89, 2432-2440.

Tepperman S 1981. Metobolic and endocrýne physiology and introductory text. 4th ed.

Velasco S, Ortiz LT, Alzueta C, Rebole A, Trevino J, Rodriguez ML 2010. Effect of inulin supplementation and dietary fat source on performance, blood serum metabolites, liver lipids, abdominal fat deposition, and tissue fatty acid composition in broiler chickens. Poult. Sci. 89, 1651-1662.

Villaverde C, Cortinas L, Barroeta AC, MartínOrúe SM, Baucells, MD 2004. Relationship between dietary unsatturation and Vitamin E in poultry. J. Anim. Physiol. and Anim. Nutr. 88, 143-149.

Zammit VA, Waterman IJ, Topping D, McKay $\mathrm{G}$ 2001. Insulin stimulation of hepatic triacylglycerol secretion and the etiology of insulin resistance. J. Nutr. 131, 20742077.

Zollitsch W, Knaus W, Aichinger F, Lettner F 1997. Effects of different dietary fat sources on performance and carcass characteristics of broilers. Anim.FeedSci. Tech. 66(1-4), 63-73. 